\title{
THE ROLE OF THE MATHEMATICAL REASONING IN CONSULTATION PROCESS ACCORDING TO GUIDANCE AND PSYCHOLOGICAL COUNSELING CANDIDATES
}

\author{
Davut Aydin, Cahit Aytekin
}

\begin{abstract}
In this research, the candidates of the Guidance and Psychological Counseling profession were asked about the role of mathematical thinking in the counseling process. Fifty candidates for Guidance and Psychological Counseling profession were participated in the research. Participants were asked to associate them with mathematical reasoning and psychological counseling process. Participants relate mathematical reasoning and services of guidance and psychological counseling to many subjects. At the end of the research, the following findings were reached such as (1) understanding the problem of the client, to realize the need more quickly, to create a goal, (2) the problem solving process in mathematics is similar to the process of solving the problem of the counselee (3) when approaching the problems of the client, it is useful in thinking fast and practical, (4) mathematical reasoning contributes to the counselor in finding a realistic and rational solution to the client's problems, (5) Mathematical reasoning makes it clear that problems can have different solutions. Thus, it directs the individual to behave as solution seeking, (6) the assumption, generalization and evidence gathering in mathematics is also present in consultation process, (7) mathematical reasoning gives the consultant multidimensional thinking and analysis of client problem.
\end{abstract}

Key words: Mathematical reasoning, Mathematical thinking, Consultation process, Candidates of guidance and psychological counselling.

\section{Introduction}

The most distinctive features that distinguish people from other creatures are their advanced thinking abilities (Alkan and Güzel, 2005). Individuals can adapt to the society they live in and they can continue their lives in this way. Individuals may face various problems in this adaptation process. In the solution process of the problems, it may be necessary to understand the problem and to develop a systematic solution to the problems by reasoning. This kind of process can be called mathematical thinking as it is stated in Suzuki (1998). The importance of developing mathematical thinking skills of students in all countries is emphasized (Keith, 2000; Mason, Burton and Stacey, 1998; Baltaci, 2016; Baki, Yildiz and Baltaci, 2012; Bukova, 2006; Baki, 2008). Mathematical thinking can be expressed as the use of mathematical knowledge and concepts previously learned by the individual, abstraction, prediction, generalization, hypothesis testing, testing, proofing, and reaching a new knowledge or comprehension with descriptions (Bukova, 2006). Baki (2008) defined mathematical thinking as the method of reaching to unknowns from the known assumptions of the given situation, gathering evidence and generalization. Liu Po-Hung (1996) is also defined mathematical reasoning as a combination of complex processes such as estimating, induction, deduction, description, generalization, sampling, formal and non-formal thinking, validation, and so on. Individuals can use their mathematical thinking in analyzing the events and phenomena they face at every stage of their lives consciously or unconsciously. Today, we can say that mathematical reasoning is a way of thinking that should be used in every field. Throughout their life, individuals try to solve problems in school and work (Blitzer, 2003). In the process of problem solving, the highest cognitive functions such as analysis, generalization and synthesis can also be used (Henson, 1993; D' Zurilla, Nezu ve Maydeu-Olivers, 2004; Naglieri and Dass, 2005). In order for students to use these functions in

Received November 2018.

Cite as: Aydın, D.; \& Aytekin, C. (2019). The role of the mathematical reasoning in consultation process according to guidance and psycholologigal counseling candidates. Acta Didactica Napocensia, 12 (1), 131-139, DOI 10.24193/adn.12.1.9. 
schools, it is necessary to contribute to their mathematical thinking. There is also a need for guidance services. Guidance services are also responsible for this.

We can improve the quality and efficiency of education by providing change and development of educational institutions, especially guidance and psychological counseling services. Guidance and psychological counseling carried out by experts has taken place in our training programs and schools as a separate aid and specialization activity. Guidance and Counseling is a movement that is born and developed in the United States as a systematic aid effort for the development of problems of the individual. Guidance and psychological counseling services are based on strong foundations as psychological, social, philosophical and economic (Tatlılığlu, 2011). The aims and principles of guidance, the way of life and education of the society must be in harmony (Bakırcioğlu, 1994). The systematic and professional help process, which is done in order for the individual to understand himself / herself, to recognize the possibilities in the environment and to be able to make the right decisions, is called as guidance (Kuzgun, 1992). According to Kepçeoğlu (1999) Psychological counseling and guidance are psychological help to the individual in order for the individual to understand himself, to solve his problems, to make realistic decisions, to improve his capacity, to make a balanced and healthy harmony with his environment and thus to realize himself. School guidance services are responsible for identifing abilities of students, directing appropriate educational branches and schools, all kinds of personal, educational and professional guidance, informing about higher education institutions, schools and businesses, solving individual problems, etc (Ministry of Education in Turkey, 1983).

Psychological counseling activities can be defined as the face to face interview relationship with the individuals with the aim of helping the development and adaptation of the individual by meeting the needs of decision making and problem solving (Yeşilyaprak, 2013). These activities can generally be associated with mathematical reasoning. Students who come to the guidance service may have more success when necessary guidance is given about mathematical reasoning. Mathematical reasoning can be expressed as a qualification to be developed to meet the needs of individuals. The process of using mathematical reasoning should be determined when the guidance and psychological counseling employees dealing with the problems of individuals. In the literature, the studies on mathematical reasoning skills are examined mostly with mathematics subjects or mathematics teacher candidates (Alkan and Güzel, 2005; Bukova-Güzel, 2008; Baltaci, 2016; Baki, Yildiz and Baltaci, 2012; Tuna, 2011) and Class and Science and Technology teacher candidates (Ersoy and Güner, 2014) and it was seen that the studies focused on especially the guidance and psychological counseling candidates did not examine about mathematical reasoning processes. However, the guidance and psychological counseling candidates should not ignore the mathematical reasoning processes while addressing the problems of their clients. Therefore, in this study; It was aimed to examine the mathematical thinking processes of the guidance and psychological counseling candidates while addressing the problems of their clients. In this context, the problem of the research is formed as "How do the guidance and psychological counseling candidates relate the problems of their clients with mathematical reasoning processes?"

\section{Method}

In this chapter, the method of the study, participants of the study, implementation process, data collection and analysis are given.

\section{1. The Method of Research}

In this study, a special case study method was used in order to have an in-depth analysis of a certain group and to examine the data without any concern for generalization. In this method, the environment, individuals or processes are evaluated and relationships are investigated (Yildırım ve Şimşek, 2008). 


\section{2. Participants}

In this research, the candidates of the Guidance and Psychological Counseling profession were asked about the role of mathematical thinking in the counseling process. Fifty candidates for Guidance and Psychological Counseling profession were participated in the research. The participants of the study consisted of third-grade students in the department of the guidance and psychological counseling at a state university in Turkey. Twelve of the participants were male and thirty-eight were female. Research was conducted at the end of the academic year. As the research was done at the end of the third year, the participants took lessons such as psychological counseling principles, group counseling, psychological counseling theories, vocational guidance and counselling and its practices.

\section{3. Data Collection Tools}

Interviews were used to collect data. Preliminary interviews were conducted with the students before starting the interview. At this preliminary interview stage, superficial information was given about the purpose of the research. Each of the interviews with the students was recorded with a digital audio recorder by obtaining the students' permissions. The interviews were conducted individually. Each interview lasted approximately 30-40 minutes. The interviews were conducted in the guidance room, a quiet environment where students would feel comfortable.

\section{4. Data Collection Tools}

Strauss and Corbin (1990) state that three types of qualitative data can be coded. These encoding types; coding according to the pre-defined concepts, coding according to the concepts extracted from the data and coding in a general framework (Punch, 2013). The data collected in the study were checked before being analyzed. During the transcript of the interviews, attention was paid to writing the interviewer-interviewed the interview as it was heard with no corrections. Next, the themes separately developed by the researcher and a field expert. In this process, the fit rate was calculated as 0.84 in the calculations using the formula of Miles and Huberman (1994). Therefore, the related information was given to field expert, too. To shape the analysis part into final form, the independent series of analysis were brought together and discussed. In the final stage of the theme analysis, one hundred percent compliance has been achieved about the themes with which there is disagreement. There is no difference of opinion among the authors about the themes given in the findings section. This was a necessary process to provide the validity of the study. On the other hand, various codes were used while presenting the findings. In this context, $R$ is the abbreviation of the researcher; $G 1$ is the abbreviation of 1st. guidance and psychological counseling candidate.

\section{Findings}

In this section, it is tried to analyze mathematical thinking processes of guidance and psychological counseling candidates. Results supported by direct quotations from interviews. In this context, the following findings were determined when the data were analyzed.

\subsection{Understanding the problem of the client, to realize the need more quickly, to create a goal}

It was determined that 26 of the 50 guidance and psychological counseling candidates participating in the research associate the mathematical reasoning with understanding the problem of the client, realizing their need more quickly and helping to create a goal. With regard to this, one of the candidates "Mathematical reasoning may be very effective and necessary in terms of analyzing the needs of the client more quickly in the consultation process, creating and evaluating the outcomes" (G50). Another candidate told this association as "I may not have experienced his experiences to understand the other person. Thefore, I always think that my point of view should be appropriate to the method of mathematical reasoning. I think that I can understand the events better with mathematical reasoning. Mathematical thinking puts me one step ahead in understanding the client's problem because I think that Mathematical reasoning keeps one's mind constantly active" (G45). It is clear that mathematical thinking from the expressions of these candidates is related to understanding the problem of the client, quick recognition and creating goals. 
3.2. The problem solving process in mathematics is similar to the process of solving the problem of the counselee.

Twenty-one of the 50 RPD candidates participating in the study likens the process of solving the problem of the counselee with the problem solving process in mathematics. For example, a candidate stated as "As well as the problem solving steps in mathematics, these steps can be used in process of problem solving in consultation" (G49). Another candidate stated as "As a solution to a math question, it is necessary to progress progressively while helping people's problems (G46)".

\subsection{When approaching the problems of the client, it is useful in thinking fast and practical.}

Twenty-one of the candidates in the study stated that mathematical thinking was useful in thinking fast and practical when approaching client's problems. For example, a PDR candidate explained this situation as "Fast and practical thinking is important for correct intervention in guidance and psychological counseling (G43)". Another candidate state as "It is important to approach the problems of the clients with more systematic and comprehension skills. So, mathematical reasoning makes practical use of our logic" (G41). Similarly, another RPD candidate expressed that "I believe a quick and systematic way is necessary in the solution of clients' problem" (G36). Accordingly, it is seen that candidates associate quick and practical thinking with mathematical reasoning when approaching clients' problems.

3.4. Mathematical reasoning contributes to the counselor in finding a realistic and rational solution to the client's problems.

In this study, 20 candidates stated that Mathematical reasoning contributes to the counselor in finding a realistic and rational solution to the client's problems. For example, a candidate explained this situation as "as a consultant, it is necessary to approach events more rationally and systematically (G21)". Another candidate highlighted as "Mathematical reasoning makes our logic more practical. Mathematical reasoning has an important effect on approaching client problems with constructive solutions and rational thoughts (G41)".

3.5. Mathematical reasoning makes it clear that problems can have different solutions. Thus, it directs the individual to behave as solution seeking.

In this study, 16 candidates stated that stated that those who developed mathematical reasonin would realize that there may be different ways of solving problems. Thus, they stated that it directs the individual to behave as solution seeking. A candidate explained that as "Clients come with a problem that needs to be solved. Mathematical reasoning is important to understand the problem, to approach it correctly and to produce solutions. Anyone who knows that there may be more than one solution with mathematical reasoning can act as a more solution-seeker, functional thinker towards life (G48)". Another candidate highlighted as "I believe there is no problem without solution" I think it will increase my desire to struggle instead of giving up (G31)".

3.6. The assumption, generalization and evidence gathering in mathematics is also present in consultation process.

In this study, 15 candidates stated that stated that the assumption and evidence gathering in mathematics is also present in consultation process. A candidate explained that as "Assumption and evidence processes are similar to the consultation process. Because, Assumption and evidence collection are applied according to the purpose of the client in the consultation process (G47)".

3.7. Mathematical reasoning gives the consultant multidimensional thinking and analysis of client problem.

In this study, 12 candidates stated that Mathematical reasoning gives the consultant multidimensional thinking and analysis of client problem. A candidate explained that as "It is important to find solutions to the problems of the client, to understand the cause and effect relationship of the problems and to find the underlying reasons (G28)". 
3.8. Mathematical reasoning is effective in predicting the possible consequences of events.

In this study, 10 candidates stated that mathematical reasoning is effective in predicting the possible consequences of events. A candidate explained that as "The purpose of the counseling service is to recognize the feelings and behaviors that the individual is not aware of. Mathematical thinking is essential because of the nature of the consultation process (G42)".

3.9. Guidance and psychological counseling are systematic and scientific, similar to mathematical thinking.

Nine of the candidates who participated in the research stated that Guidance and psychological counseling is similar to the definition of mathematical thinking because of its systematic and scientific nature. A candidate explained that as "guidance and psychological counseling services such as mathematical reasoning also occur systematically (G30)". Another teacher candidate explained directly as "guidance and psychological counseling services are systematic and scientific (G48)".

3.10. Guidance and psychological counseling services have multiple solutions such as math problems.

Candidates who participated in the study stated that there was more than one solution in services as well as in mathematics. In this respect, he made a connection between mathematical thinking and guidance and psychological counseling services. A candidate explained this view as "I think mathematical reasoning will help me to see that there may be more than one solution to problems of clients (G31)".

\subsection{Inferences can be made about what the client did not tell.}

Eight of the candidates participating in the research have stated that sometimes, it is possible to predict the things that the client has not explained yet. One candidate explained as "I think that will be effective in reaching the unknown known (G1)". Another candidate stated that "It is important to understand the reason for the feelings of the client so what the client tells us is important to understand the emotions. (G6)"

\subsection{Mathematical reasoning allows us to look at events objective and rational.}

Two of the canditates participating in the research indicated that mathematical reasoning would provide us to look more objective and rational the events in the client process. "Psychological counselor can provide solution in a more objective way by using the problem solving steps in the solution part" stated by a cantidate (G40) to emphazise the importance of mathematical reasoning.

3.13. Some clients may not want to accept that their problems can be solved in accordance with the mathematical logic.

Two of the participants stated that "some clients may not want to accept that their problems can be solved in accordance with the mathematical logic". One of the participants stated that "In some cases, the client may be uncomfortable looking at his or her experiences from a mathematical point of view. This can damage the counseling process. Because a supervisor with high mathematical reasoning can reflect this to the client. Some clients may be disturbed by the systematic solution to their problems Since the results are clear and precise in mathematics, the client may not accept this way of solving his / her own problem. (G50)".

3.14. The events are quickly evaluated while conducting mathematical reasoning. Therefore, it is not suitable for guidance and psychological counseling.

One of the participants stated that "The events are quickly evaluated while conducting mathematical reasoning. Therefore, it is not suitable for guidance and psychological counselling". 
Table 1. Themes regarding the role of mathematical thinking in the process of counseling process according to the opinions of candidates for guidance and psychological counseling cantidates.

\begin{tabular}{|l|l|c|}
\hline & \multicolumn{1}{|c|}{ Themes } & f \\
\hline 1 & $\begin{array}{l}\text { Understanding the problem of the client, to realize the need more quickly, to } \\
\text { create a goal }\end{array}$ & 26 \\
\hline 2 & $\begin{array}{l}\text { The problem solving process in mathematics is similar to the process of solving } \\
\text { the problem of the counselee. }\end{array}$ & 23 \\
\hline 3 & $\begin{array}{l}\text { When approaching the problems of the client, it is useful in thinking fast and } \\
\text { practical. }\end{array}$ & 21 \\
\hline 4 & $\begin{array}{l}\text { Mathematical reasoning contributes to the counselor in finding a realistic and } \\
\text { rational solution to the client's problems. }\end{array}$ & 20 \\
\hline 5 & $\begin{array}{l}\text { Mathematical reasoning makes it clear that problems can have different solutions. } \\
\text { Thus, it directs the individual to behave as solution seeking. }\end{array}$ & 16 \\
\hline 6 & $\begin{array}{l}\text { The assumption, generalization and evidence gathering in mathematics is also } \\
\text { present in consultation process. }\end{array}$ & 15 \\
\hline 7 & $\begin{array}{l}\text { Mathematical reasoning gives the consultant multidimensional thinking and } \\
\text { analysis of client problem. }\end{array}$ & 12 \\
\hline 8 & $\begin{array}{l}\text { Mathematical reasoning is effective in predicting the possible consequences of } \\
\text { events. }\end{array}$ & $\begin{array}{l}\text { Guidance and psychological counseling are systematic and scientific, similar to } \\
\text { mathematical thinking. }\end{array}$ \\
\hline 10 & $\begin{array}{l}\text { Guidance and psychological counseling services have multiple solutions such as } \\
\text { math problems. }\end{array}$ & 8 \\
\hline 11 & Inferences can be made about what the client did not tell. & 8 \\
\hline 12 & Mathematical reasoning allows us to look at events objective and rational. \\
\hline 13 & $\begin{array}{l}\text { Some clients may not want to accept that their problems can be solved in } \\
\text { accordance with the mathematical logic. } \\
\text { The events are quickly evaluated while conducting mathematical reasoning. } \\
\text { Therefore, it is not suitable for guidance and psychological counseling. }\end{array}$ & 1 \\
\hline 14 & 2 \\
\hline
\end{tabular}

\section{Discussion and Conclusions}

It was determined that twenty-six of the fifty participants participated in this research stated that mathematical thinking is useful about understanding the problem of the client, to realize the need more quickly, to create a goal. Sevgen (2002) mentioned in his study about that mathematical thinking is important in order for people to give meaning to the events systematically and precisely. In this case, we can refer to mathematical thinking as an expression of Tall (1995) as an individual's attempt to perceive objects around them and make meaningful relations between them. Guidance services play an important role in helping students to get to know themselves better, to be aware of their characteristics, to recognize their opportunities and options, to make realistic decisions, to realize themselves, to cope with the problems they face, and to adapt to their environment (Güven, 2006). Therefore, it can be said that the relationship between mathematical reasoning and guidance and psychological counseling services is compatible with the literature.

The majority of the participants likens the process of solving the problem of the client with the problem solving process in mathematics. Mathematical reasoning can be thought to be limited to the effective use of mathematical principles and rules. However, this thought does not fully explain mathematical reasoning. However, mathematical reasoning processes are used with or without awareness of all kinds of problem solving in life (Henderson, 2002). We can say that the individual will need to think mathematically in his / her life, as he tries to solve problems in school, work and life (Blitzer, 2003). On the other hand, eight of the participants stated that there is more than one solution in Guidance and Psychological Counseling services. In this respect, they stated that they resemble solving the math problem with the Guidance and Psychological Counseling services. Sixteen participants stated that high level mathematical reasoning could find different solutions to problems. Thus, they stated that those with advanced mathematical reasoning will be oriented as solution seeker towards life. In addition, twelve of the Guidance and Psychological Counseling candidates who 
participated in the study stated that mathematical thinking provided the ability to think and analyze the problems of the mentee with different perspectives. Eldeleklioğlu and Özkilıç (2016) stated that Guidance and Psychological Counseling candidates should be able to look at a problem they encounter in their daily lives from different perspectives. "Thinking with a different perspective" is one of the problem solving methods (Posementer and Krulik, 1998) that Guidance and Psychological Counseling candidates apply with or without awareness.

Twenty said that mathematical thinking was useful in thinking fast and practical when approaching client problems. Twenty participants expressed that mathematical thinking contributed to finding the best and rational solution to the problems of the client. Külahoğlu (2004) also stated that the development of communication skills should be included in classroom guidance and decision making processes. As Umay (2007) states, mathematical thinking is the process of reaching a rational decision by evaluating the current knowledge and process and taking into account all possibilities. This study, which emphasizes the importance of mathematical reasoning in the guidance and psychological counseling process, coincides with Umay's (2007) definition.

Fifteen participants stated that the assumptions of mathematics, evidence gathering and generalization processes were also used in the consultation process. Ten participants stated that mathematical reasoning was effective in predicting the possible consequences of events. If we use high-level thinking skills such as assumption, evidence collection, generalization, estimation, control in our daily life, we can say that we actually use mathematical reasoning. For this reason, it can be said that candidates for guidance and psychological counseling can use mathematical reasoning processes using such high-level thinking skills. Nine of the participants stated that this field is systematic and scientific and it is similar to the definition of mathematical reasoning. Two participants stated that the mathematical reasoning would provide a more objective and rational look at the events during the consultation process. On the other hand, a participant said that the client may not accept that their problems can be solved in accordance with the mathematical logic. Yalçın (2006) examined the professional duties and responsibilities of the counselor and emphasized that there are many variables related to academic, social and emotional development. One participant stated that the expression of a quick approach to events in the definition of mathematical reasoning did not conform to the profession of guidance and psychological counseling. We can say that this participant does not overlap the definition of mathematical reasoning and guidance and psychological counseling services.

\section{References}

Alkan, H., \& Güzel, B. E. (2005). Öğretmen adaylarında matematiksel düşünmenin gelişimi [Development of mathematical thinking in the student teachers], Gazi Üniversitesi Gazi Eğitim Fakültesi Dergisi, 25(3), 221-236.

Bakırcıoğlu, R. (1994). Rehberlik ve Psikolojik Danışma (4. Baskı). Turhan Kitabevi, Ankara.

Baki, A. (2008). Kuramdan uygulamaya matematik eğitimi. Harf Yayınc1lık, Trabzon.

Baltaci, S. (2016). Examination of gifted students' probability problem solving process in terms of mathematical thinking. Malaysian Online Journal of Educational Technology (MOJET), 4(4), 18-35.

Baki, A., Yıldı, A., \& Baltaci, S. (2012). Mathematical thinking skills shown by gifted students while solving problems in a computer-aided environment. Energy Education Science and Technology Part B: Social and Educational Studies, SpecialIssue, 993-995.

Blitzer, R., (2003). Thinking mathematically. Upper Saddle River, NJ: Prentice Hall.

Bukova, E., (2006). Öğrencilerin Limit Kavramını Algılamasında ve Diğer Kavramlarla İlişkilendirilmesinde Karşılaştıkları Güçlükleri Ortadan Kaldıracak Yeni Bir Program Geliştirme. Yayınlanmamış doktora tezi, Dokuz Eylül Üniversitesi Eğitim Bilimleri Enstitüsü, İzmir.

Bukova-Güzel, E. (2008). Yapılandırmacılık Ve Matematiksel Düşünme Süreçleri. Education Sciences, 3(4), 678-688. 
D'Zurilla, T. J., Nezu, A. M. \& Maydeu-Oliveras, A. (2004). Social problem solving: theory and assesment. Social problem solving: theory, research and training, Ec. Chang, T.J. D'Zurilla and L.J. SaFnna, (Ed.), Washington DC: American Psychological Association.

Eldeleklioğlu, J., \& Özkılıç, R. (2016). Eleştirel düşünme eğitiminin RPD öğrencilerinin eleştirel düşünme becerilerine etkisi. Türk Psikolojik Danışma ve Rehberlik Dergisi, 3(29).

Ersoy, E., \& Güner, P. (2014). Matematik öğretimi ve matematiksel düşünme. Eğitim ve Öğretim Araştırmaları Dergisi, 3(2), 102-112.

Güven, M. (2006). Okullarda rehberlik servisleri-hizmetleri. A. Kaya içinde, Psikolojik Danışma ve Rehberlik (3. b., s. 63-91). Ankara: Anı Yayınc1lik.

Henderson, P. (2002). Materials development in support of mathematical thinking, $<$ http://blue.butler.edu/phenders/iticse2002WG.rtf $>$ Son erişim 15/12/2004.

Henson, K. T. (1993). Methods and strategies for teaching in secondary and middle schools. Longman Publishing Group.

Keith, D. (2000). Finding Your Inner Mathematician. Chronicle of Higher Education, 47(5), 5-6.

Kepçeoğlu, M. (1999). Psikolojik danışma ve rehberlik. İstanbul: Alkım Yayıncılık.

Kuzgun, Y. (1992). Psikolojik danışma ve rehberlik. Ankara: ÖSYM.

Külahoğlu, Ş. (2004). Okul psikolojik danışman ve rehberlik programlarının geliştirilmesi (2. Baskı). Ankara: Pegem Akademi Yayıncılık.

Liu P. H (1996), Do teachers need to incorporate the history of mathematics in their teaching? The Mathematics Teacher. Reston: Sep.Vol.96, Iss. 6; pg. 416.

Mason, J., Burton, L. \& Stacey, K. (1998). Thinking Mathematically. Addison-Wesley Publisher Limited.

MEB (1982). Talim ve Terbiye Kurulu Başkanlığı.

Miles, M. B. \& Huberman, A.M. (1994). Qualitative data analysis: an expanded sourcebook. (2nd Edition). Calif: SAGE Publications.

Naglieri, J. A. \& Das, J. P. (2005). Planning, Attention, Simultaneous, Successive (PASS) Theory: A Revision of the Concept of Intelligence (120-135). In: D. P. Flanagan \& P. L. Harrison (Eds.) Contemporary Intellectual Assessment. New York: The Guilford Press.

Posamentier, A. S. \& Krulik, S. (1998). Problem-Solving Strategies for Efficient and Elegant Solutions. A Researce for the Mathematics Teacher. California: Corwin Press.

Punch, K. F. (2013). Introduction to social research: Quantitative and qualitative approaches (3th ed.).. Sage. London.

Sevgen, B. (2002), Matematiksel Düşünce Yapısı ve Gelişimi, V. Ulusal Fen Bilimleri ve Matematik Eğitimi kongresi, 16-18-Eylül-2002, Ortadoğu Teknik Üniversitesi, Ankara.

Strauss, A. \& Corbin, J. (1990). Basics of qualitative research. Newbury Park, CA: Sage.

Suzuki, K. (1998). Measuring "to think mathematically": Cognitive characterization of achievement levels in performance-based assessment. Unpublished doctoral dissertatioan, University of Illinois at Urbana-Champaign.

Tall, D. (1995), Cognitive Growth in Elementary and Advenced Mathematical Thinking, Proceedings of the International Conference for the Psychology of Mathematics Education, Recife, Brazil: I, 161 175.

Tatlılığlu, K. (2011). Rehberlik ve psikolojik danışmanlık servisinden beklentiler üzerine bir araştırma [A research on expectations from psychologicial counseling and guidance services] Bingöl Üniversitesi Sosyal Bilimler Enstitüsü Dergisi, 1(1), 79-102. 
Tuna, A. (2011). Trigonometri Öğretiminde 5E Öğrenme Döngüsü Modelinin Öğrencilerin Matematiksel Düşünme Ve Akademik Başarılarına Etkisi [The effect of the 5E learning cycle modelon students' mathematical thinking and academic achievements in teaching trigonometry]. Yayımlanmış Doktora Tezi, Gazi Üniversitesi Eğitim Bilimleri Enstitüsü, Ankara.

Umay, A. (2007). Eski arkadaşımız okul matematiğinin yeni yüzü. Ankara.

Yalçın, İ. (2006). 21. Yüzyılda psikolojik danışman. Ankara Üniversitesi Eğitim Bilimleri Fakültesi Dergisi, 39(1), 117-133.

Yeşilyaprak, B. (2013). 21. Yüzyılda eğitimde rehberlik hizmetleri gelişimsel yaklaşım. 21. Baskı. Ankara: Nobel Yayıncilik.

Yıldırım, A., \& Şimşek, H. (2008). Sosyal bilimlerde nitel araştırma yöntemleri (6. bs). Ankara: Seçkin Yayıncılık.

\section{Authors}

Davut AYDIN, Assist. Prof. Dr., Ahi Evran University, Faculty of Education, the Department of Guidance and Psychological Counseling, Kırşehir, TURKEY, e-mail: drdavuta@gmail.com

Cahit AYTEKİN, Assist. Prof. Dr., Ahi Evran University, Faculty of Education, the Department of Mathematics Education, Kırşehir, TURKEY, e-mail: caytekin1@ gmail.com 
